\title{
THE FIRST RURAL PUBLIC HOSPITAL
}

\author{
by Virginia $M$. Luckey
}

The following article was written by Miss Luckey when she was a third year medical student at Howard University, Washington, D.C. It first appeared in the March 1960 issue of the Journal of the Iowa Medical Society and is reprinted here with permission.

The progress in the practice of medicine, since its earliest beginnings, has been intimately associated with several other institutions that have been present in the successive societies. The centers for the teaching and the practice of medicine began in the temples, and then slowly moved to the spas, to the medieval universities and finally to the hospitals as we now know them.

The development of the hospital has been a significant part of the history of medicine and of humanity. Thus, it is especially rewarding to look into the conception and development of a particular institution, one which serves as an almost forgotten landmark in the history of hospital development and medical care in the United States.

The Washington County Hospital in Washington, Iowa, still serves the people of its county, as it has done every day since July 16, 1912 when it opened its doors as the first rural county hospital in the United States. It paved the way for an entirely new era in medical care.

Although there were many large and famous hospitals in the United States at the turn of the century, none of them could be found in the rural areas of the nation. Hospital care, unless one lived close to a large city, was virtually unavailable. Then, here and there, small groups of rural physicians recognized the value of hospital facilities both in providing care for their patients and in advancing their own education. They organized small private hospitals. In Washington, the Washington City Hospital was created in 1907 by a group of local doctors and a nurse, in whose house it was located, and 
the worth of this tiny (five bed) institution was heartily endorsed, a few years later, when the question of constructing a tax-financed county hospital was put to a vote of the county residents.

The legislation which allowed the proposal for the construction of a county hospital to be put to the voters of Washington County was the first of its kind in the United States.

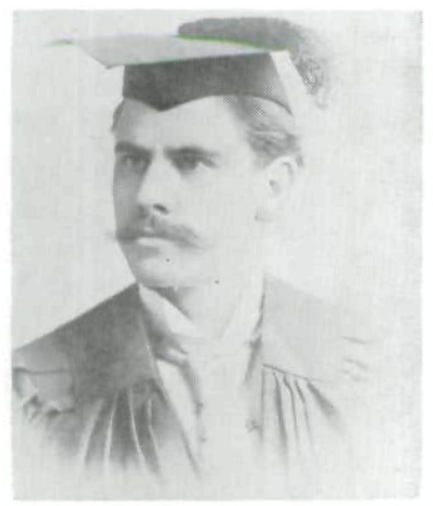

E. E. Munger, M.D.

The sponsor of the proposal, E. E. Munger, M.D., was a physician from Spencer, in the opposite corner of Iowa. His ingenuity, courage and tireless concern in helping to solve the hospital problem for rural areas has never been adequately recognized. His was then a radically new idea. Realizing the desperate need of all rural people for hospital care, he wrote and secured legislative support for a bill designed to permit residents of a county to vote a special tax upon themselves for the construction and maintenance of a county hospital that would serve all county residents. The Munger Bill, as it came to be known, passed the State Legislature in 1910.

The Washington physicians had watched the progress of the Munger Bill in the Legislature, and had a carefully planned campaign to be put into effect as soon as the law passed. In the summer of 1910, when the governor's signature on the new law had scarcely dried, a petition was secured from the necessary number of freeholders, and the proposal for a Washington County Hospital was to appear on the ballot at the November election. During the three months or more that intervened, nothing much was done until the last week before the election.

During the week prior to election day, however, the Washington County Medical Society unleashed a barrage of 
campaign material. Every conceivable means of communication was used. Leaflets and handbills were given to storekeepers for inclusion in their packages, and schoolchildren were given materials by their teachers. On November 8 , the day before the election, every newspaper in the county published an editorial urging adoption of the resolution.

When the ballots were counted, the measure had carried by a larger majority than had been expected. The whirlwind campaign during the last few days before the election had been so sudden and overwhelming that "the opponents were never able to arouse any organized opposition."

Out of the eight counties in which the voters' approval was sought for the construction of county hospitals that first year, Washington was the only one in which the campaign was conducted in this manner, and it was the only one in which approval was secured. In the other seven counties, the attempts had to be repeated at later elections.

Although $\$ 25,000$ had been appropriated for the construc of the Washington County Hospital, it was soon discovered that the building, as planned, would require some $\$ 10,000$ or $\$ 15,000$ more than the original sum. After a great deal of discussion and some opposition, various individuals and organizations contributed money and equipment sufficient to permit the continuance of the project. An 11-acre tract of land on the edge of town was donated for the site of the hospital by Mr. W. P. Wells. Thus, when the hospital opened its doors on July 16, 1912, it had been built and equipped for a cost of $\$ 41,000$ and had a capacity of 35 or 40 beds.

Curiously enough, although the hospital had been built to serve Washington County residents, as either paying or non-paying patients, the first two individuals admitted were non-residents. Quite accidentally, the first surgical patient was a resident of Dr. Munger's community who had been taken ill more than 200 miles from home while visiting her son in Washington. The hospital had been open for two days before receiving that first patient. The second one was a tramp who had collapsed on a downtown Washington street. 
Steadily throughout the past 47 years [1960 figure], the Washington County Hospital has helped to teach both the physicians of the area and the people of the county the advantages of hospital care. In addition it served during its early years as a model rural hospital, and it was closely watched and frequently visited by people from other states and counties who were interested in establishing like institutions.

During its first year of operation, 131 patients were admitted, but during 1957 a total of 1,140 patients spent 10,385 patient days there. The entire budget of the hospital has always come from local taxes, patient fees and private gifts. No federal tax money has ever come to the hospital.

By 1939, it became evident that the hospital's capacity was no longer adequate. In June 1940, an election was successfully carried, and an additional 15 beds became available in 1942, giving the institution its present capacity of 54 beds and 13 cribs.

With the advent of improved roads and other means of transportation, and particularly since the introduction of more complicated, technical and expensive medical procedures and equipment, the wisdom of further construction of such small community and county hospitals has become debatable. But regardless of their future, the service which these hospitals have rendered is evidenced by the fact that within a short time after the passage of the Munger Bill in Iowa more than 14 other states adopted similar legislation and built numerous small hospitals.

The brightest and busiest era of the rural public hospital may be drawing to a close in many parts of the nation, but many thousands of rural people will continue to depend upon them for care in most of their illnesses. Doctors, too, will continue to benefit from the exchanges of medical ideas that take place there and from the scientific programs that they occasionally sponsor.

The physicians privileged to use the Washington County Hospital are sure to remember Dr. Munger, for a bronze plaque, presented to the institution in June 1947, in the 35th year of its operation, commemorates the man with whom 
and the place in which a new concept in hospital care begana man and a place that have been important in the health care of rural people and in the continuing education of country doctors.

The plaque is inscribed:

IN MEMORIAM, ELBERT ERVIN MUNGER, M.D., 1867-1946, PHYSICIAN, AMERICAN HUMANITARIAN, AUTHOR OF THE RURAL COUNTY PUBLIC HOSPITAL LAW UNDER WHICH THIS HOSPITAL WAS THE FIRST BUILT IN THE NATION. THIS PLAQUE IS PRESENTED BY HIS CHILDREN TO THE CITIZENS OF WASHINGTON COUNTY, IOWA.

\section{FROM THE EDITOR'S DESK . . .}

- Of interest to students of Fairfield and Jefferson County history is a new book by Susan Fulton Welty, A Fair Field (Harlo Press, Detroit, Mich. 434 pages, index, price $\$ 7.50)$.

- The Iowa Civil War Centennial Commission has recently published Years of Valor by Edith Wasson McElroy. The paper-back centers around a fictitious Iowa family during 1863-1865. 258 pages, price $\$ 3$. Copies may be ordered from the author at 1141 28th Street, West Des Moines 50265.

- A conference on the history of the Trans-Mississippi West will be held at the University of Kansas in honor of Prof. George Anderson. The meeting, to be held on Oct. 16 and 17, 1969, will include sessions devoted to regional development, Indian policy and economic growth. Among the participants will be Allan Bogue, Robert Johannsen, Oscar Winther, Paul Gates, Rodman Paul, Francis Prucha, William Hagan, Earl Pomeroy and Vernon Carstensen. For further information, write Dana Seibengood, University Extension Building, Lawrence, Kan. 66044.

- Articles to appear in future ANNALS include "The Great Railroad Raid" by Edwin C. Bearss of Washington, D. C. and "E. T. Meredith and the Farm Problem (19211928)" by Dr. Catherine Grollman of Coralville, Iowa. 
Copyright of Annals of Iowa is the property of State of Iowa, by \& through the State Historical Society of Iowa and its content may not be copied or emailed to multiple sites or posted to a listserv without the copyright holder's express written permission. However, users may print, download, or email articles for individual use. 